\title{
IN VITRO CALCIFIED MATRIX DEPOSITION BY HUMAN OSTEOBLASTS ONTO A ZINC-CONTAINING BIOACTIVE GLASS
}

Enrica Saino $^{1,7}$, Stefania Grandi ${ }^{2,7}$, Eliana Quartarone ${ }^{2,7}$, Valentina Maliardi ${ }^{3,7}$, Daniela Galli ${ }^{3,7}$, Nora Bloise ${ }^{1}$, Lorenzo Fassina $^{4,7}$, Maria Gabriella Cusella De Angelis ${ }^{3,7}$, Piercarlo Mustarelli2, ${ }^{2,7}$, Marcello Imbriani ${ }^{5,6}$ and Livia Visai ${ }^{1,5,7^{*}}$

\author{
${ }^{1}$ Department of Biochemistry, Medicine Section, Via Taramelli 3/B, 27100 Pavia, Italy \\ ${ }^{2}$ Department of Physical Chemistry, Via Taramelli 16, 27100 Pavia, Italy \\ ${ }^{3}$ Department of Experimental Medicine, Via Forlanini 8, 27100 Pavia, Italy \\ ${ }^{4}$ Department of Computer and Systems Science, Via Ferrata 1, 27100 Pavia, Italy \\ ${ }^{5}$ Salvatore Maugeri Foundation IRCCS,Via S. Maugeri 4, 27100 Pavia, Italy \\ ${ }^{6}$ Department of Preventive, Occupational Medicine and Public Health, University of Pavia,Via S. Maugeri 4, 27100 \\ Pavia, Italy \\ ${ }^{7}$ Center for Tissue Engineering (C.I.T), Via Ferrata 1, 27100 Pavia, Italy
}

\begin{abstract}
Bioactive glasses synthesized by the sol-gel technique possess many of the qualities associated with an ideal scaffold material for a bone graft substitute. In view of the potential clinical applications, we performed a detailed in vitro study of the biological reactivity of synthesized $58 \mathrm{~S}$ bioactive glass containing-zinc, in terms of osteoblast morphology, proliferation, and deposition of a mineralized extracellular matrix (ECM). Human Sarcoma Osteoblast (SAOS-2) cells were used to i) assess cytotoxicity by lactate dehydrogenase $(\mathrm{LDH})$ release and ii) evaluate the deposition of a calcified extracellular matrix by ELISA assay and quantitative RT-PCR (qRT-PCR). In comparison with pure silica and $58 \mathrm{~S}$, the $58 \mathrm{~S}-\mathrm{Zn} 0.4$ bioglass showed a significant increase in cellular proliferation and deposition of ECM components such as decorin, fibronectin, osteocalcin, osteonectin, osteopontin, type-I and -III collagens. Calcium deposition was significantly higher than on pure silica and 58S samples. Also Alkaline phosphatase (ALP) activity and its protein content was higher with respect to pure silica and 58S. qRT-PCR analysis revealed the up-regulation of type-I collagen, bone sialoprotein and osteopontin genes. All together these results demonstrate the cytocompatibility of $58 \mathrm{~S}-\mathrm{Zn} 0.4$ bioglass and its capability to promote osteoblast differentiation.
\end{abstract}

Keywords: Sol-gel bioactive glass, zinc-containing bioactive glass, silica, osteoblasts, mineralization, extracellular matrix deposition.

\footnotetext{
* Address for correspondence:

Livia Visai

Pavia University, Department of Biochemistry - Medicine Section, Via Taramelli, 3/B, 27100 Pavia -Italy

Telephone Number: +390382987725

FAX Number: +390382423108

E-mail: lvisai@unipv.it
}

\section{Introduction}

The concept of bioactive glass (bioglass) was developed and tested for the first time by Hench at the beginning of the 70s (Hench et al., 1971; Hench and Paschall, 1973). Since then, several glass and glass-ceramic compositions have been synthesized (Li et al., 1991; Hench, 1998; Lusvardi et al., 2002; Vallet-Regí et al., 2003; Linati et al., 2005; Vallet-Regi, 2006; Izquierdo-Barba et al., 2008). The common characteristic of bioglass (Oliva et al., 1998) - a comprehensive name including glass and glassceramics - is that, upon implantation, their surface undergoes complex kinetic modifications leading to the formation of an amorphous calcium phosphate layer. Within a few days, this layer crystallizes into a biologically active hydroxycarbonate apatite (HCA) phase (Hench et al., 1973), which is chemically and structurally equivalent to the mineral phase in bone and is responsible for interfacial bonding. The same biologically active layer can be formed even by immersing bioglass in an acellular simulated body fluid (SBF), with ion concentrations and $\mathrm{pH}$ resembling those of human blood plasma (Kokubo et al., 1990; Ohtsuki et al., 1992). The apatite forming ability test using SBF is a controversial tool, but simple one to investigate the in vitro apatite forming ability of material surfaces.

Bioglass composition is commonly based on $\mathrm{SiO}_{2}$ and $\mathrm{P}_{2} \mathrm{O}_{5}$ for glassy network formers, and on $\mathrm{CaO}$ and $\mathrm{Na}_{2} \mathrm{O}$ for network modifiers; only some of the possible compositions are bioactive (Hench et al., 1971). In the early 1990s, sol-gel methods (Brinker and Scherer, 1990) were introduced for bioglass synthesis and found to present relevant advantages when compared to standard melt-quenching techniques. In particular, these methods extended the $\mathrm{SiO}_{2}$ limit to about $90 \mathrm{~mol} \%$ beyond which the samples lose their bioactivity (Li et al., 1991). The bioactivity of glass can also be improved by adding intermediate or modifying oxides to the base compositions. It was shown that the addition of $\mathrm{ZnO}$ to standard bioglass could stimulate osteoblast proliferation and differentiation, thus improving the implant's ability to bond with bone (Oki et al., 2004). The addition of $\mathrm{ZnO}$ up to $\sim 15 \mathrm{~mol} \%$ to standard melt-quenched bioglass was studied by combining several experimental techniques (thermal measurement, X-Ray diffraction, solid-state NMR), and Molecular Dynamics (Lusvardi et al., 2002; 
Linati et al., 2005). Zinc is known to have stimulatory effects on bone formation in vitro and in vivo (WHO, 1973; Yamaguchi et al., 1986; Yamaguchi et al., 1987). In fact, the slow release of zinc incorporated into an implanted material promotes bone formation around the implant and accelerates the patient's recovery (Ito et al., 2002; Yamaguchi et al., 2004). In particular, zinc promotes the bioglass chemical durability in aqueous solutions such as body fluids, and improves its mechanical properties (Ito et al., 2002). Recently, it was shown that zinc extends the specific surface area and thereby the number of sites for the nucleation of calcium phosphate precipitates in binary $\mathrm{SiO}_{2}-\mathrm{CaO}$ sol-gel glasses (Courtheoux et al., 2008).

Concerning cytocompatibility, melt-quenched bioglasses with a zinc content in the range 5-20 mol\% showed significant cytotoxicity against human osteoblasts (Aina et al., 2007). In contrast, Balamurugan et al. reported a minimal cytotoxicity with sol-gel glass composition of (mol\%) 64\% $\mathrm{SiO}_{2}, 26 \% \mathrm{CaO}, 5 \% \mathrm{P}_{2} \mathrm{O}_{5}, 5 \% \mathrm{ZnO}$ towards murine osteoblasts (Balamurugan et al., 2007). In a companion paper, we presented evidence of good bioactivity and cytocompatibility for a 58S-based bioglass with the following composition: $59.7 \mathrm{~mol} \% \mathrm{SiO}_{2}-36.2$ $\mathrm{mol} \% \mathrm{CaO}-3.8 \mathrm{~mol} \% \mathrm{P}_{2} \mathrm{O}_{5}-0.3 \mathrm{~mol} \%$ (0.4 wt $\%$ ) $\mathrm{ZnO}$ (58S-Zn0.4) (Bini et al., 2009). In the same paper we showed that the addition of larger quantities of $\mathrm{ZnO}$ resulted in increased cytotoxicity vs. SAOS-2 cells. On the other hand, it is important to check the possibility to extend the cytocompatibility range of $\mathrm{ZnO}$, since this additive could positively modify the physico-chemical properties of the bioglass. The availability of more detailed cytotoxicity studies is also desirable because of the contradictory results reported in the literature (e.g., Aina et al., 2007; Balamurugan et al., 2007) which, however, may be dependent on many factors, including cell line, synthesis routes and related glass microstructure, surface morphology, zinc release kinetics, etc.

The aim of the present study was to perform a detailed investigation of zinc-containing bioglasses, in terms of osteoblast morphology, proliferation, and deposition of a mineralized extracellular matrix. Some data on other 58Sbased glasses were reported for the sake of comparison, and pure silica and $58 \mathrm{~S}$ were used as reference materials. Considering the clinical applications of bioactive glass in dentistry, maxillofacial and orthopaedic surgery, the final scope of the work was to produce an improved scaffold for bone grafts. The main novelty of our study can be found in the wide approach followed in testing the cytocompatibility of the bioglass.

\section{Materials and Methods}

\section{Bioglass synthesis and characterization Glass synthesis}

Pure silica and 58S bioglasses with and without $\mathrm{ZnO}$ were synthesized by sol-gel routes (Brinker and Scherer, 1990). The compositions and some physico-chemical properties are provided in Table 1 . We report here, the detailed synthesis of the $58 \mathrm{~S}$ sample. $133.2 \mathrm{ml}$ of TEOS (98 $\mathrm{wt} \%$ ) were added to $42 \mathrm{ml}$ of an $\mathrm{HCl} 0.01 \mathrm{~N}$ aqueous solution and mixed with $180.4 \mathrm{ml}$ ethanol. The mixture was stirred for about 15 min until hydrolysis was almost complete. Then, $18.4 \mathrm{~g}$ of triethylphosphate were added and the solution was stirred for $20 \mathrm{~min}$. Finally, $112 \mathrm{~g}$ of Ca( $\left.\mathrm{NO}_{3}\right)_{2}$ $4 \mathrm{H}_{2} \mathrm{O}$ were dissolved in the sol during $20 \mathrm{~min}$ of magnetic stirring. Gelation occurred after about three days. More details are reported in Bini et al. (2009).

After gelation, all samples were dried at $65^{\circ} \mathrm{C}$ for 24 hours and then at $90^{\circ} \mathrm{C}$ for 24 hours. Finally, they were finely crushed and placed in an oven for the stabilization treatment: heating with $0.3{ }^{\circ} \mathrm{C} / \mathrm{min}$ up to $700^{\circ} \mathrm{C}$, isotherm for $3 \mathrm{~h}$ at $700^{\circ} \mathrm{C}$, and then cooling to room temperature. The flowing atmosphere was $\mathrm{N}_{2}(0.3 \mathrm{l} / \mathrm{min})$ and $\mathrm{O}_{2}(0.3 \mathrm{l} /$ $\mathrm{min})$. The gel-powder was ball-milled and sieved. The fraction of particles with a diameter between 20 and 45 $\mu \mathrm{m}$ was selected for the preparation of the pellets. The pellets (10 $\mathrm{mm}$ diameter and $1.5 \mathrm{~mm}$ high) were obtained by compacting $0.25 \mathrm{~g}$ of the gel powder by monoaxial pressing at 2 ton for $5 \mathrm{~min}$ followed by isostatic pressing at 2500 tons for $5 \mathrm{~min}$

\section{Physico-chemical characterization}

$\mathrm{N}_{2}$ adsorption isotherms were obtained from pellets previously treated at $300^{\circ} \mathrm{C}$ under vacuum for $12 \mathrm{~h}$, with a Carlo Erba Sorptomatic 1990. The data were analyzed with the Brunauer, Emmett and Teller (BET) algorithm. The size distribution of the meso- and macropores up to

Table 1. Physico-chemical properties of the bioglass disks.

\begin{tabular}{|c|c|c|c|c|c|c|c|c|c|}
\hline \multirow[b]{2}{*}{ Sample } & \multicolumn{4}{|c|}{ Composition } & \multirow[b]{2}{*}{$\begin{array}{c}\text { Structure } \\
\text { (X-rays) }\end{array}$} & \multirow[b]{2}{*}{$\begin{array}{c}\text { Surface } \\
\text { area } \\
\left(\mathbf{m}^{2} / \mathbf{g}\right)\end{array}$} & \multirow{2}{*}{$\begin{array}{c}\text { Pore } \\
\text { specific } \\
\text { volume } \\
\left(\mathrm{cm}^{3} / \mathrm{g}\right)\end{array}$} & \multirow[b]{2}{*}{$\begin{array}{c}\text { Pore } \\
\text { diameter } \\
(\mathbf{n m})\end{array}$} & \multirow[b]{2}{*}{$\begin{array}{r}\text { Density } \\
\left(\mathrm{g} / \mathrm{cm}^{3}\right)\end{array}$} \\
\hline & $\begin{array}{c}\mathrm{SiO}_{2} \\
(\mathrm{~mol} \%)\end{array}$ & $\begin{array}{c}\mathrm{CaO} \\
(\mathrm{mol} \%)\end{array}$ & $\begin{array}{c}\mathrm{P}_{2} \mathrm{O}_{5} \\
(\mathbf{m o l} \%)\end{array}$ & $\begin{array}{c}\mathrm{ZnO} / \mathrm{ZnO} \\
(\mathrm{mol} \% \text { / wt \%) }\end{array}$ & & & & & \\
\hline Silica & 100 & - & - & - & amorphous & 424 & 0.59 & 7.5 & 2.08 \\
\hline $58 \mathrm{~S}$ & 59.7 & 36.4 & 3.9 & - & glass/ceramic & 64 & 0.05 & 2.8 & 2.45 \\
\hline $58 \mathrm{~S}-\mathrm{Zn} 0.4$ & 59.7 & 36.2 & 3.8 & $0.3 / 0.4$ & glass/ceramic & 79 & 0.19 & 4.0 & 2.45 \\
\hline $58 \mathrm{~S}-\mathrm{Zn} 2$ & 59.7 & 35.2 & 3.5 & $1.6 / 2$ & glass/ceramic & 137 & 0.20 & 3.6 & 2.60 \\
\hline $58 \mathrm{~S}-\mathrm{Zn} 5$ & 59.7 & 33.7 & 2.8 & $3.8 / 5$ & glass/ceramic & 88 & 0.21 & 4.0 & 2.67 \\
\hline
\end{tabular}


$300 \mathrm{~nm}$ was investigated by applying the Barret, Joyner and Halenda (BJH) method on the desorption isotherms. The skeletal density was determined by using the helium pycnometer Micromeritics (Norcross, GA, USA) Accupyc 1330 .

The X-ray powder diffraction measurements (XRPD) were performed with a Bruker AXS (Madison, WI, USA) $\mathrm{D} 5005$ diffractometer (CuK $\alpha$ radiation). The angular range of collection was $10^{\circ} \leq 2 \theta \leq 65^{\circ}$, with the step $0.015^{\circ}$ step and the counting time of $0.5 \mathrm{~s} / \mathrm{step}$. A PSD detector and a nickel filter were used. The structure and profile refinements were performed on the basis of the Rietveld method with TOPAS 3.0 software (Bruker AXS, 2005).

\section{In vitro apatite forming ability test in $\mathrm{SBF}$}

The pellets were sterilized for 3 hours at $180^{\circ} \mathrm{C}$. Then, 40 $\mathrm{ml}$ of SBF (Kokubo et al., 1990) solution were filtered with a Millipore ${ }^{\circledR}$ membrane (pore size $0.22 \mu \mathrm{m}$ ), and decanted to a beaker. The disks were maintained at $37^{\circ} \mathrm{C}$ for 1, 5 and 8 days, then the SBF solution was removed and the pellets washed with sterile distilled water and dried at $100^{\circ} \mathrm{C}$ for 24 hours. All of the SBF test steps were performed in a lamellar flow fume hood to maintain sterility. At the end of each treatment time, the amount of the HCA phase was determined by X-ray diffraction (Bini et al., 2009).

\section{Surface roughness and topographical characterization}

The surface morphology of the disks was observed by scanning electron microscopy with a Leica Cambridge Stereoscan 440 microscope (Leica Microsystems, Bensheim, Germany).

Surface-roughness measurements were performed with a UBM (Sunnyvale, CA, USA) laser profilometer. Five linear measures were performed for each material according to the standard method DIN 4768. Three roughness parameters $\left(\mathrm{R}_{\mathrm{a}}, \mathrm{R}_{\mathrm{q}}\right.$ and $\left.\mathrm{R}_{\mathrm{z}}\right)$ were considered. Essentially, $\mathrm{R}_{\mathrm{a}}$ is the arithmetic average of the absolute values of all data points; $R_{q}$ is the root mean square of the profile values; $R_{z}$ is the arithmetic mean of the maximum peak-to-valley height of the roughness values of five consecutive sample sections.

\section{In vitro cell assays \\ Cells}

The human osteosarcoma cell line SAOS-2 was obtained from the American Type Culture Collection (HTB85, ATCC, Manassas, VA, USA). The cells were cultured in McCoy's 5A modified medium with L-glutamine and HEPES (Cambrex Bio Science, Baltimore, MD, USA), supplemented with $15 \%$ foetal bovine serum, $2 \%$ sodium pyruvate, $1 \%$ antibiotics, $10^{-8} \mathrm{M}$ dexamethasone, and 10 mM $\beta$-glycerophosphate (Sigma-Aldrich, St. Louis, MO, USA) (Saino et al., 2010). The osteogenic factor $\beta$ glycerophosphate was used at $10 \mathrm{mM}$ concentration as previously reported in the literature (Rao et al., 2003; Gartland et al., 2005). Ascorbic acid, another osteogenic supplement, is a component of McCoy's 5A modified medium. For comparative analysis without osteogenic factors, the SAOS-2 cells were also grown in the previous indicated culture medium without dexamethasone and $\beta$ glycerophosphate. The cells were cultured at $37^{\circ} \mathrm{C}$ with $5 \% \mathrm{CO}_{2}$, routinely trypsinized after confluency, counted, and seeded onto disks.

\section{Cell seeding and culture}

Bioglass disks were sterilized by ethylene oxide at $38^{\circ} \mathrm{C}$ for $8 \mathrm{~h}$ at $65 \%$ relative humidity. After $24 \mathrm{~h}$ aeration in order to remove the residual ethylene oxide, the scaffolds were placed inside a standard 24-well-plate and were washed first with sterile distilled water, after with $0,9 \%$ $\mathrm{NaCl}$ sterile solution and finally with culture medium. A cell suspension of $2 \times 10^{5}$ cells was added onto the top of each disk and, after $0.5 \mathrm{~h}, 1 \mathrm{~mL}$ of culture medium with/ without osteogenic factors was added to cover the samples. The culture medium was changed every three days.

\section{LDH assays}

Four disks for each sample were sterilized at $180^{\circ} \mathrm{C}$ for three hours, placed inside standard 24-well-plates, washed several times with physiological solution and with culture medium in order to remove possible sol-gel toxic residue. After further washing, a suspension of $2 \times 10^{5}$ SAOS- 2 cells $(0.4 \mathrm{ml})$ was added on top of each pellet, incubated for $1 \mathrm{~h}$ to allow cell attachment and then covered with $0.5 \mathrm{ml}$ of culture medium. The plates were incubated for 24 and 48 hours at $37^{\circ} \mathrm{C}$ with $5 \% \mathrm{CO}_{2}$. At the end of the incubation time, the LDH assay (Sigma-Aldrich) was performed following the manufacturer's instructions. The absorbance was measured at $490 \mathrm{~nm}$ and $690 \mathrm{~nm}$ with a microplate reader (BioRad, Segrate (MI), Italy) and the number of cells was determined with an appropriate calibration curve. The results were similar for both incubation times.

\section{Scanning electron microscopy (SEM) analysis}

At the end of culture incubation, the disks were fixed with $2.5 \%(\mathrm{v} / \mathrm{v})$ glutaraldehyde solution in $0.1 \mathrm{M} \mathrm{Na}$-cacodylate buffer $(\mathrm{pH}=7.2)$ for $1 \mathrm{~h}$ at $4^{\circ} \mathrm{C}$, washed with Na-cacodylate buffer, and then dehydrated at room temperature in an ethanol gradient series up to $100 \%$. The samples were kept in $100 \%$ ethanol for $15 \mathrm{~min}$, and then critical point-dried with $\mathrm{CO}_{2}$. The specimens were sputter coated with gold and observed at 250x and 1500x magnification respectively with a Leica Cambridge Stereoscan 440 microscope (Leica Microsystems, Bensheim, Germany) at $8 \mathrm{kV}$ (Saino et al., 2010).

\section{3-(4,5-dimethylthiazole-2-yl)-2,5-diphenyl tetrazolium bromide test}

To evaluate the mitochondrial activity of the seeded cells, that is, the cell viability on the bioglass disks during the culture period, a test with 3-(4,5-dimethylthiazole-2-yl)2,5-diphenyl tetrazolium bromide (MTT) (Sigma-Aldrich), was performed on days 1, 8, 16, and 24 (end of the culture period) as previously reported (Saino et al., 2010). Aliquots of $200 \mu \mathrm{L}$ were sampled, and the related absorbance values were measured at $570 \mathrm{~nm}$ by a microplate reader (BioRad Laboratories, Hercules, CA, USA). A standard curve of cell viability was used to express the results as a percentage. 


\section{DNA content}

At the end of incubation, the cells were lysed by a freezethaw method in sterile deionised distilled water. The released DNA content was evaluated with a fluorometric DNA quantification kit (PicoGreen; Molecular Probes, Eugene, OR, USA). A DNA standard curve (Saino et al., 2010) obtained from a known amount of osteoblasts was used to express the results as cell number per disk.

\section{Purified proteins}

Decorin, type-I collagen and fibronectin were purified as described previously (Vuento and Vaheri, 1979; Vogel and Evanko, 1987; Rossi et al., 1996); osteocalcin was acquired from Biomedical Technologies (Stoughton, MA, USA), osteopontin and osteonectin were obtained from Assay Designs (Ann Arbor, MI, USA); type-III collagen and alkaline phosphatase were purchased from Sigma-Aldrich.

\section{Polyclonal antisera}

Dr. Larry W. Fisher (http://csdb.nidcr.nih.gov/csdb/ antisera.htm, National Institutes of Health, Bethesda, MD, USA) provided us with the rabbit polyclonal anti type-I and -III collagen, anti-decorin, anti-osteopontin, antiosteocalcin, anti-osteonectin, and anti-alkaline phosphatase. Polyclonal antibody against human fibronectin (HFn) was produced as previously described (Saino et al., 2010).

Extraction of the extracellular matrix proteins from the cultured scaffolds and ELISA assay

At the end of the culture period, in order to evaluate the amount of the extracellular matrix constituents on the disk surface, the samples were washed extensively with sterile PBS to remove the culture medium, and then incubated for $24 \mathrm{~h}$ at $37^{\circ} \mathrm{C}$ with $1 \mathrm{~mL}$ of sterile sample buffer $(20$ $\mathrm{mM}$ Tris- $\mathrm{HCl}, 4 \mathrm{M} \mathrm{GuHCl}, 10 \mathrm{mM}$ EDTA, 0,066\% [w/v] $\mathrm{SDS}, \mathrm{pH} 8.0$ ). At the end of the incubation period, sample buffer aliquots were removed, and then the disks were centrifuged at $4000 \mathrm{rpm}$ for $15 \mathrm{~min}$ in order to collect the sample buffer entrapped inside the pores. The total protein concentration in both culture systems was evaluated with the BCA Protein Assay Kit (Pierce Biotechnology, Rockford, IL, USA). After matrix extraction, the disks were incubated, once again, for $24 \mathrm{~h}$ at $37^{\circ} \mathrm{C}$ with $1 \mathrm{~mL}$ sterile sample buffer, and no protein was detected.

Calibration curves to measure type-I and -III collagens, decorin, osteopontin, osteocalcin, osteonectin, fibronectin and alkaline phosphatase were performed as previously described (Saino et al., 2010). In order to measure the extracellular matrix amount of each protein an ELISA assay was performed as previously reported (Saino et al., 2010).

We have taken into consideration that an underestimation of the absolute protein deposition is possible because the sample buffer, used for matrix extraction, contained sodium dodecyl sulphate - which may interfere with protein adsorption during the ELISA assay. The amount of extracellular matrix constituents from both samples was expressed as fg/(cell per disk).

\section{Calcium quantification}

In order to evaluate calcium deposition on silica, $58 \mathrm{~S}$ and $58 \mathrm{~S}-\mathrm{Zn} 0.4$ bioglass disks, the calcium-cresolphthalein complexone method was performed as previously described (Cohen and Sideman, 1979) on cells cultured with/without osteogenic factors. Briefly, the calcium content of each disk was assayed to quantify the amount of mineralized matrix present, using a Calcium Fast kit (Mercury SPA, Naples, Italy) according to the manufacturer's instructions as previously described (Saino et al., 2010). Samples were run in triplicate and compared against the calibration curve of standards.

\section{ALP activity}

ALP activity was determined using a colorimetric end point assay (Holtorf et al., 2005). The assay measures the conversion of the colourless substrate p-nitrophenol phosphate (PNPP) by the enzyme ALP to the yellow product $\mathrm{p}$-nitrophenol, where the rate of colour change corresponds to the amount of enzyme present in solution. The test was performed as previously described (Saino et al., 2010) on cells cultured with/without osteogenic factors. Samples were run in triplicate and compared against the calibration curve of p-nitrophenol standards. The enzyme activity was expressed as micromoles of $\mathrm{p}$ nitrophenol produced per min per mg of enzyme.

\section{Assay for gene expression}

At the end of the culture period, total RNA was extracted from the cultured disks using the Trizolâ reagent, according to the manufacturer's protocol (Invitrogen, Carlsbad, CA, USA). Reverse transcriptase-polymerase chain reaction (RT-PCR) was performed in order to evaluate the gene expression for bone sialoprotein (BSP), decorin (DEC), fibronectin (FN), osteocalcin (OC), osteopontin (OP), typeI collagen (COLI), type-III collagen (COLIII), human transforming growth factor beta (TGF $\beta$ ), bone sialoprotein (BOSP), bone morphogenetic protein 2 (BMP-2) and the housekeeping gene expression for glyceraldehyde-3phosphate dehydrogenase (GAPDH). The reverse transcriptase reaction was performed with $300 \mathrm{ng}$ total RNA using the iScript ${ }^{\mathrm{TM}}$ cDNA Synthesis kit from BioRad. The primers (Primm s.r.l., Milan, Italy) were designed according to the published gene sequences, and the polymerase chain reactions were performed with the GeneAmp PCR System 9700 (Applied Biosystems, Foster City, CA, USA) as previously reported (Saino et al., 2010). The primers used are indicated in Table 2.

\section{Real-time PCR}

Total RNA from the chemically treated samples (treat) and the non chemically treated samples (control) was extracted with Trizol reagent (Invitrogen) and retro-transcribed in c-DNA with the iScriptä cDNA Synthesis Kit (BioRad Laboratories). A quantitative RT-PCR analysis was performed in a 48-well optical reaction plate using a MiniOpticon Real Time PCR System (BioRad Laboratories) as previously described (Saino et al., 2010). 
Table 2. Primers used for RT-PCR.

\begin{tabular}{|l|l|l|c|}
\hline \multicolumn{1}{|c|}{ Genes } & \multicolumn{1}{|c|}{ Upstream primer } & \multicolumn{1}{c|}{ Downstream primer } & Amplicon size (bp) \\
\hline ALP & 5'-ACCTCGTTGACACCTGGAAG-3' & 5'-CCACCATCTCGGAGAGTGAC-3' & 189 \\
\hline BMP-2 & 5'-AACGGACATTCGGTCCTTGC-3' & 5'-CGCAACTCGAACTCGCTCAG-3'’ & 284 \\
\hline BOSP & 5'-TGAGGCTGAGAATACCACAC-3' & 5'-GCCTAGTGGTGTGTTCTTAG-3' & 380 \\
\hline COL I & 5'-TGTAAGCGGTGGTGGTTATG-3' & 5'-GGTAGCCATTTCCTTGGAAG-3' & 450 \\
\hline COL III & 5'-TGGATCAGATGGTCTTCCA-3' & 5'-TCTCCATAATACGGGGCAA-3' & 620 \\
\hline DEC & 5'-CGAGTGGTCCAGTGTTCTGA-3' & 5'-AAAGCCCCATTTTCAATTCC-3' & 400 \\
\hline FN & 5'-TGGAACTTCTACCAGTGCGAC-3' & 5'-TGTCTTCCCATCATCGTAACAC-3' & 500 \\
\hline GAPDH & 5'-TTCACCACCATGGAGAAGGC-3' & 5'-GGCATGGACTGTGGTCATGA-3' & 236 \\
\hline TGF- $\beta$ & 5'-GTGCGGCAGCTCTACATTGACT-3' & 5'-TTGCGGCCCACGTAGTACAC -3' & 230 \\
\hline OC & 5'-GGCAGCGAGGTAGTGAAGAG-3' & 5'-CTGGAGAGGAGCAGAACTGG-3' & 230 \\
\hline OP & 5'-TCACTGATTTTCCCACGGAC-3' & 5'-TCATAACTGTCCTTCCCACG-3' & 280 \\
\hline
\end{tabular}

The test was performed on cells cultured with/without osteogenic factors. Oligonucleotide primers were designed based on gene sequences published in GenBank (www.ncbi.nlm.nih.gov/genbank).

\section{Statistics}

Seventy five disks were used in each repeated experiment (25 silica disks, 25 58S disks and 25 58S-Zn0.4 disks). Each experiment was repeated three times. Results are expressed as the mean \pm standard deviation. In order to compare the results between the two types of disks, the one-way analysis of variance (ANOVA) with post hoc Bonferroni test was applied, with a significance level of 0.05 .

\section{Results}

\section{HCA formation}

Fig. 1 shows the weight percentages of the HCA crystalline phase, as determined by Rietveld refinement of the X-ray diffractograms, vs. the immersion time in SBF. For a detailed discussion on the limitations of the Rietveld analysis and related errors see Bini et al. (2009). Pure silica displayed no HCA formation following treatment with SBF. The presence of zinc clearly increased the HCA formation rate. In fact, the sample with $5 \%$ wt zinc showed more than $90 \%$ HCA crystalline phase already after one day of immersion in SBF.

\section{Cytotoxicity assay}

Fig. 2 illustrates the cytocompatibility results obtained with the LDH assay. After 48 hours incubation, pure silica and the $58 \mathrm{~S}$ sample (reference material) showed an increase in cell population numbers. Worse results were obtained

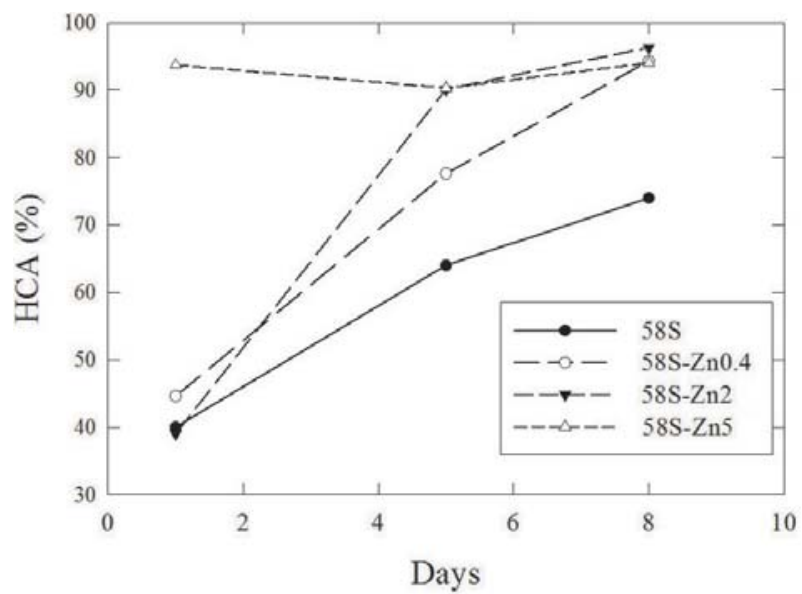

Fig. 1. Weight percentages of HCA as a function of the soaking time in SBF (days) for the $58 \mathrm{~S}$ sample and for bioglass with zinc. The lines serve as a visual guide.

with the samples containing 2 and $5 \%$ wt $\mathrm{ZnO}$. The sample with only $0.4 \% \mathrm{wt} \mathrm{ZnO}$ showed a cytocompatibility level nearly equal to that of pure silica and 58S. For this reason, this composition was chosen, together with pure silica and $58 \mathrm{~S}$, to perform all the other analyses on osteoblast proliferation, and mineralized extracellular matrix deposition.

\section{Surface morphology and roughness of the bioglass disks}

The $R_{a}, R_{q}$ and $R_{z}$ roughness parameter values are shown in Table 3. Differences were observed between the samples analyzed, the 58S-Zn0.4 sample exhibited the highest roughness value followed by silica and $58 \mathrm{~S}$.

SEM images of the surface topographies confirmed the roughness parameter results (Fig 3, panels A, C and 


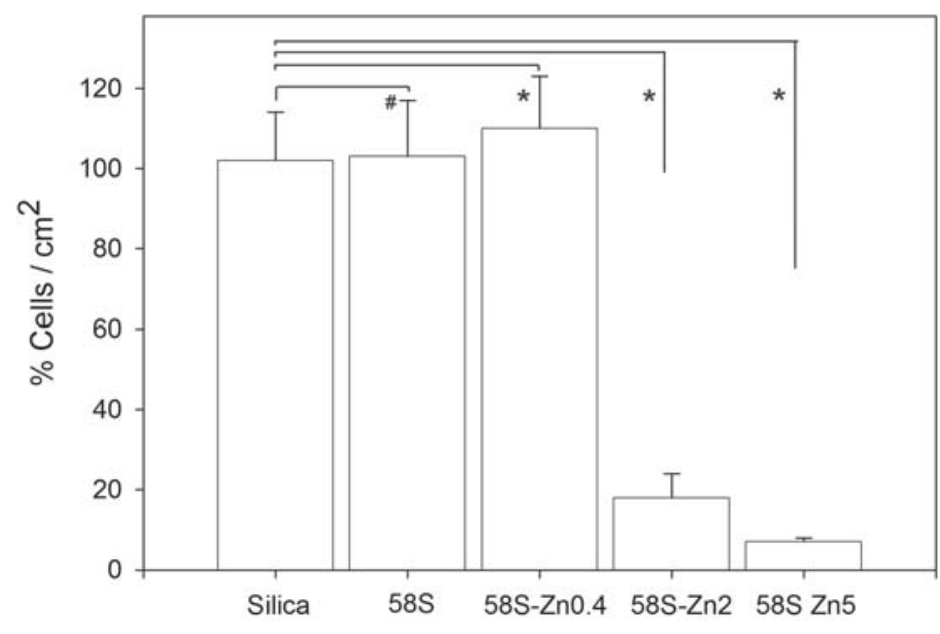

Fig. 2. Cell viability results (cells attached to the samples) after 48 hours incubation, as determined by the LDH assay on pure silica, $58 \mathrm{~S}$ and bioglass disks containing $0.4 \%$ wt $\mathrm{ZnO}$. The error bars represent the standard deviations.

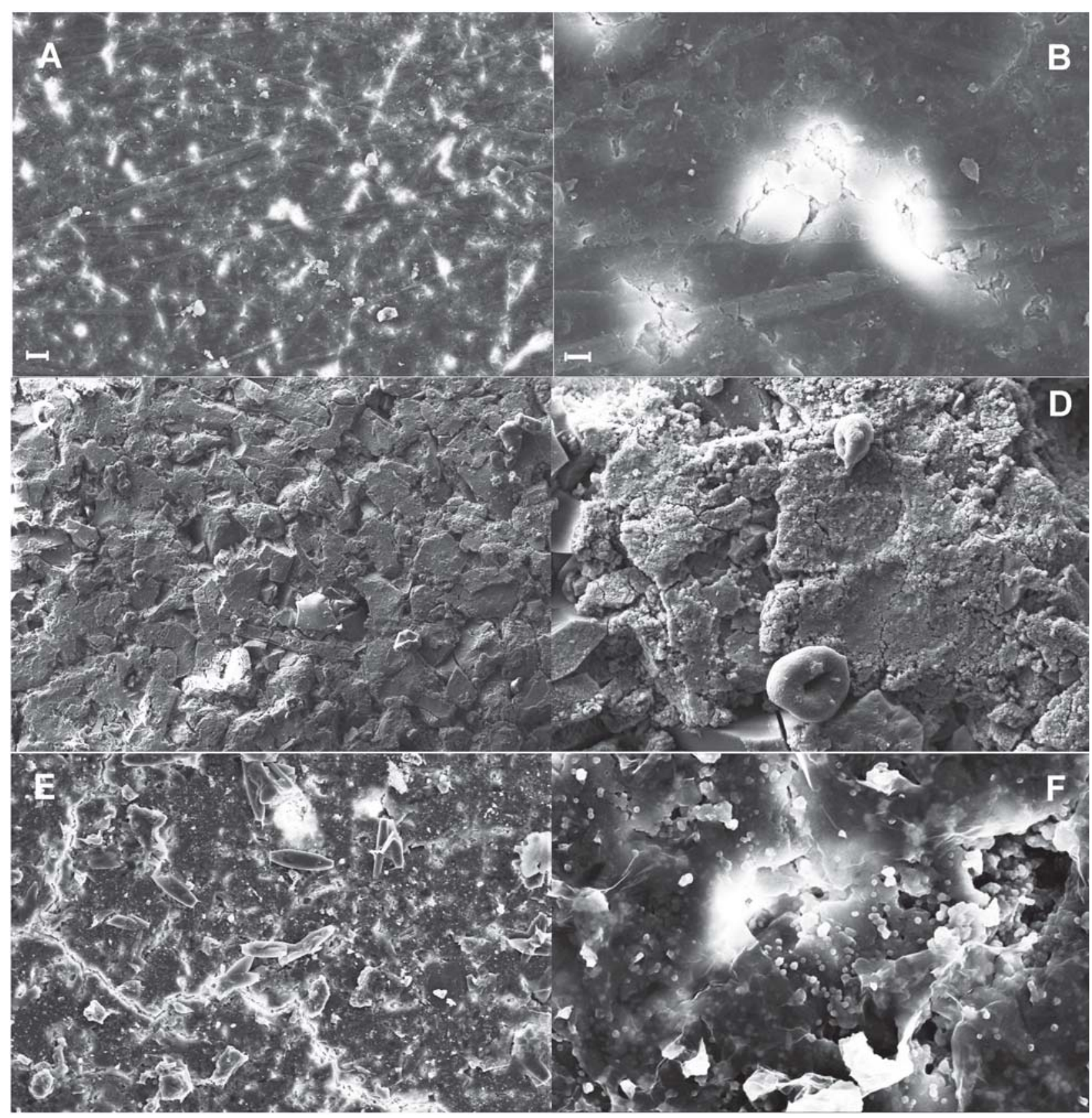

Fig. 3. SEM images of unseeded disks at 250x (A, C, D) and 1500x (B, D, F) magnification; silica disks (A, B), 58S (C, D) and bioglass disks containing $0.4 \% \mathrm{wt} \mathrm{ZnO}$ (E, F). 


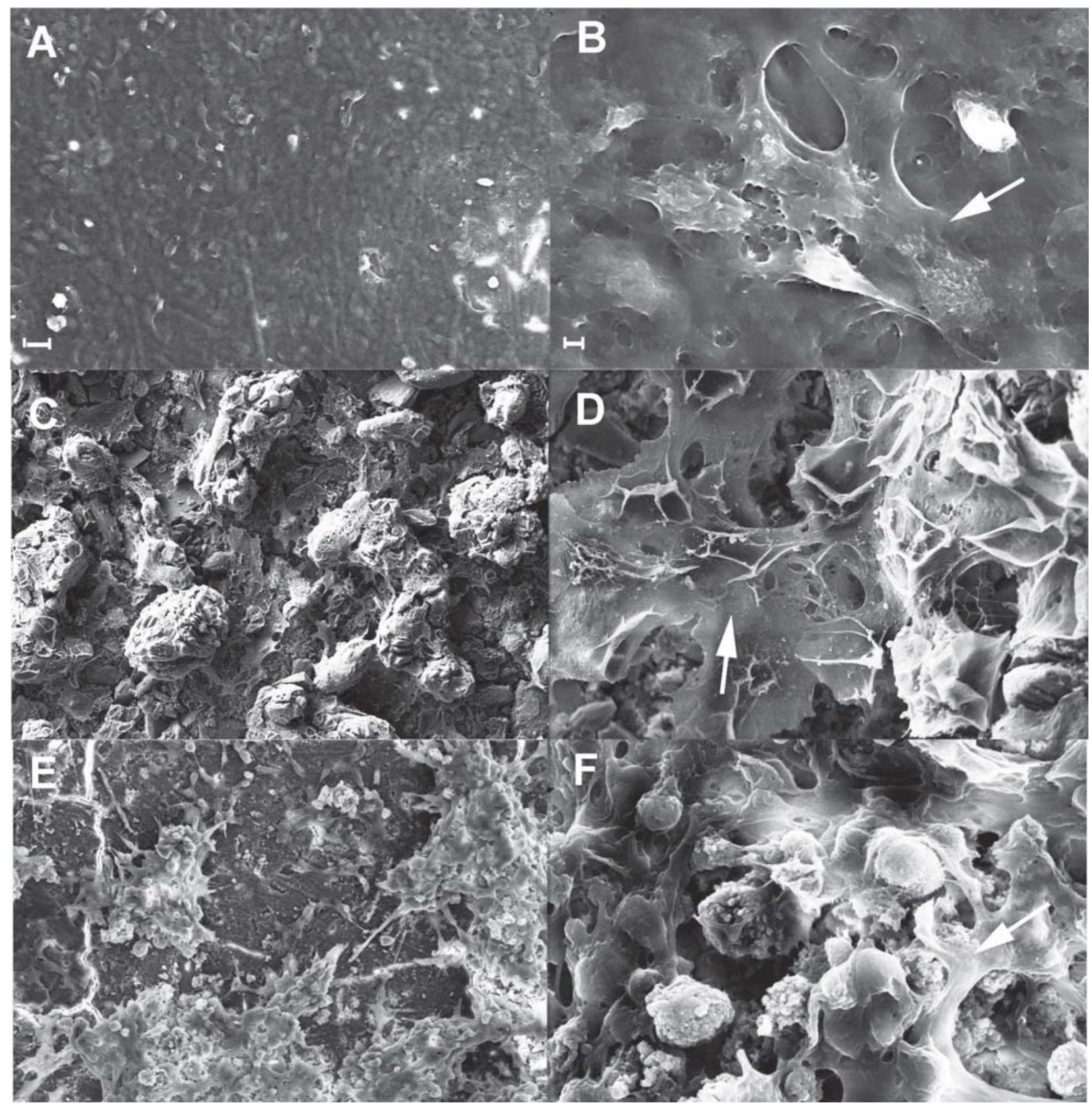

Fig. 4. Representative SEM images of the cell cultured silica disks (panel A), 58S disks (panel C) and bioglass disks containing $0.4 \%$ wt $\mathrm{ZnO}$ (panel D) at 250x magnification, respectively. On the silica and 58S disks, the osteoblasts were well dispersed (panels B and D, 1500x magnification); on the bioglass disks containing $0.4 \% \mathrm{wt}$ $\mathrm{ZnO}$, individual osteoblasts were no longer discernable over the surface and above this layer some cells exhibited a round shape (panel F, 1.500x magnification). Scale bars represent $10 \mu \mathrm{m}(\mathbf{A}, \mathbf{C}, \mathbf{E})$ and $2 \mu \mathrm{m}(\mathbf{B}, \mathbf{D}, \mathbf{F})$, respectively. White arrows are positioned to indicate SAOS-2 cells.

E). At higher magnification, the surface of all sample types appeared non homogeneous and somewhat rough (Fig 3, panels B, D and F): in particular the surface of 58S-Zn0.4 was characterized by some cracks (panel F).

\section{Cell morphology and viability}

SAOS-2 cell morphology cultured on the silica, $58 \mathrm{~S}$ and 58S-Zn0.4 disks was visualized by SEM (Fig. 4). Figure 4 is a representative image of 24 days in cell culture showing adherence of cells to the surface of all types of bioglass. In particular, the cells more homogeneously covered the surface of the 58S-Zn0.4 sample than that of the silica and 58S disks (Fig. 4, panels A, C and E). However, on the
Table 3. Surface roughness parameters for the different surfaces. $\mathrm{R}_{\mathrm{a}}$ is the arithmetic average of the absolute height values of the profile; $\mathrm{R}_{\mathrm{q}}$ is the root mean square of the values of the profile; $\mathrm{R}_{\mathrm{z}}$ is the maximum peak-tovalley height of the entire measurement area.

\begin{tabular}{|c|c|c|c|}
\hline Sample & $\mathbf{R}_{\mathbf{a}}(\boldsymbol{\mu} \mathbf{m})$ & $\mathbf{R}_{\mathbf{q}}(\boldsymbol{\mu} \mathbf{m})$ & $\mathbf{R}_{\mathbf{z}}(\boldsymbol{\mu} \mathbf{m})$ \\
\hline Silica & $2.375 \pm 0.0012$ & $3.084 \pm 0.0014$ & $17.848 \pm 0.0011$ \\
\hline $\mathbf{5 8 S}$ & $0.755 \pm 0.0020$ & $0.941 \pm 0.0012$ & $5.516 \pm 0.0013$ \\
\hline $\mathbf{5 8 S - Z n 0 , 4}$ & $4.386 \pm 0.0011$ & $5.752 \pm 0.0013$ & $31.696 \pm 0.0014$ \\
\hline
\end{tabular}



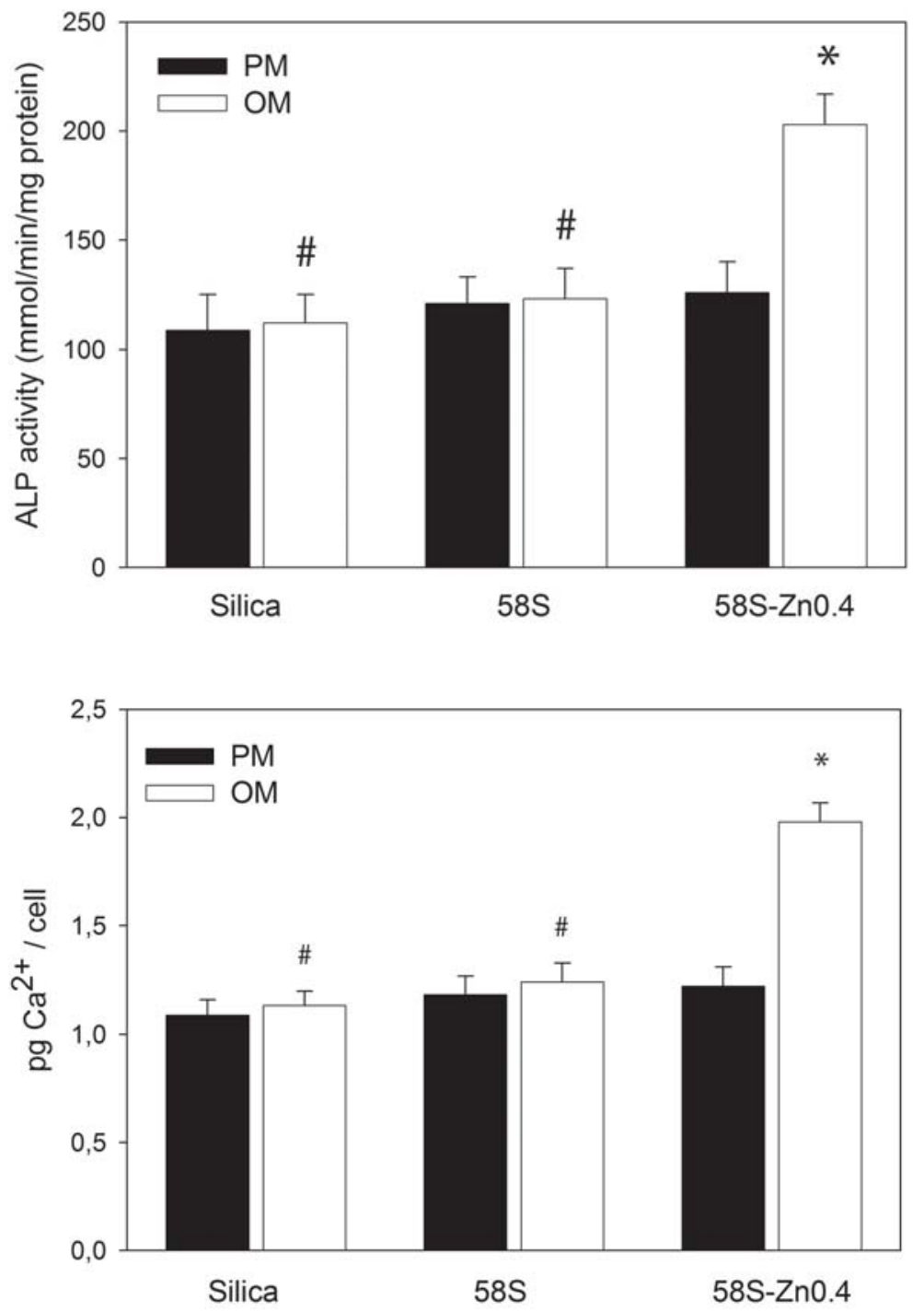

Fig. 5. ALP activity of SAOS-2 cells seeded onto silica, $58 \mathrm{~S}$ and $58 \mathrm{~S}-\mathrm{Zn} 0.4$ disks and cultured in proliferative medium (PM) or in osteogenic medium (OM). ALP activity was determined colourimetrically, corrected for the protein content measured with the BCA Protein Assay Kit and expressed as millimoles of p-nitrophenol produced per min per $\mathrm{mg}$ of protein. Bars express the mean values \pm SEM of results from three experiments (\# $p>0.05$; $* p<0.05$ ).

Fig. 6. Mineralization of extracellular matrix produced by SAOS-2 cells seeded onto silica, $58 \mathrm{~S}$ and and $58 \mathrm{~S}-\mathrm{Zn} 0.4$ disks and cultured in proliferative medium (PM) or in osteogenic medium (OM) as determined by quantification of calcium content. Results are expressed on a per-scaffold basis and are presented as an average \pm standard deviation (\# $p>0.05 ; * p<0.05$ ).

Table 4. Normalized amount of the extracellular matrix constituents secreted and deposited onto the disks $(p<0.05$ in the comparison " $58 \mathrm{~S}-\mathrm{Zn} 0,4 \%$ vs. $58 \mathrm{~S}$ " and" $58 \mathrm{~S}-\mathrm{Zn} 0,4 \%$ vs. silica"). In comparison with the silica and $58 \mathrm{~S}$ disks, the use of zinc promoted a better deposition of bone extracellular proteins onto the entire surface.

\begin{tabular}{|c|c|c|c|c|c|}
\cline { 2 - 6 } \multicolumn{1}{c|}{} & \multicolumn{4}{c}{ Matrix protein deposition after 27 days of cell culture in fg/(cell $\boldsymbol{x}$ disk) } \\
\cline { 2 - 6 } & Silica & 585 & $58 S-Z n 0.4$ & $58 S-Z n 0.4 /$ Silica & 58 -Zno.4/58S \\
\hline Alkaline Phosphatase & $18.13 \pm 1.2$ & $19.13 \pm 1.2$ & $36.3 \pm 0.9$ & 2.0 & 1.9 \\
\hline Decorin & $15.0 \pm 1.3$ & $15.7 \pm 1.2$ & $16.5 \pm 0.7$ & 1.1 & 1.1 \\
\hline Fibronectin & $5.5 \pm 0.5$ & $5.8 \pm 0.8$ & $6.1 \pm 0.6$ & 1.1 & 1.1 \\
\hline Osteocalcin & $6.4 \pm 0.6$ & $6.9 \pm 0.6$ & $8.8 \pm 0.5$ & 1.4 & 1.3 \\
\hline Osteonectin & $3.0 \pm 0.8$ & $3.0 \pm 0.8$ & $3.8 \pm 0.6$ & 1.3 & 1.3 \\
\hline Osteopontin & $3.3 \pm 0.5$ & $3.7 \pm 0.7$ & $6.2 \pm 1.1$ & 1.9 & 1.8 \\
\hline Type-I collagen & $23.45 \pm 1.1$ & $25.65 \pm 1.1$ & $46.8 \pm 0.2$ & 2.0 & 1.1 \\
\hline Type-III collagen & $7.6 \pm 0.3$ & $7.8 \pm 0.3$ & $8.6 \pm 0.4$ & 1.2 & \\
\hline
\end{tabular}




\section{Silica $58 \mathrm{~S} \quad 58 \mathrm{~S}-\mathrm{Zn} 0.4$}
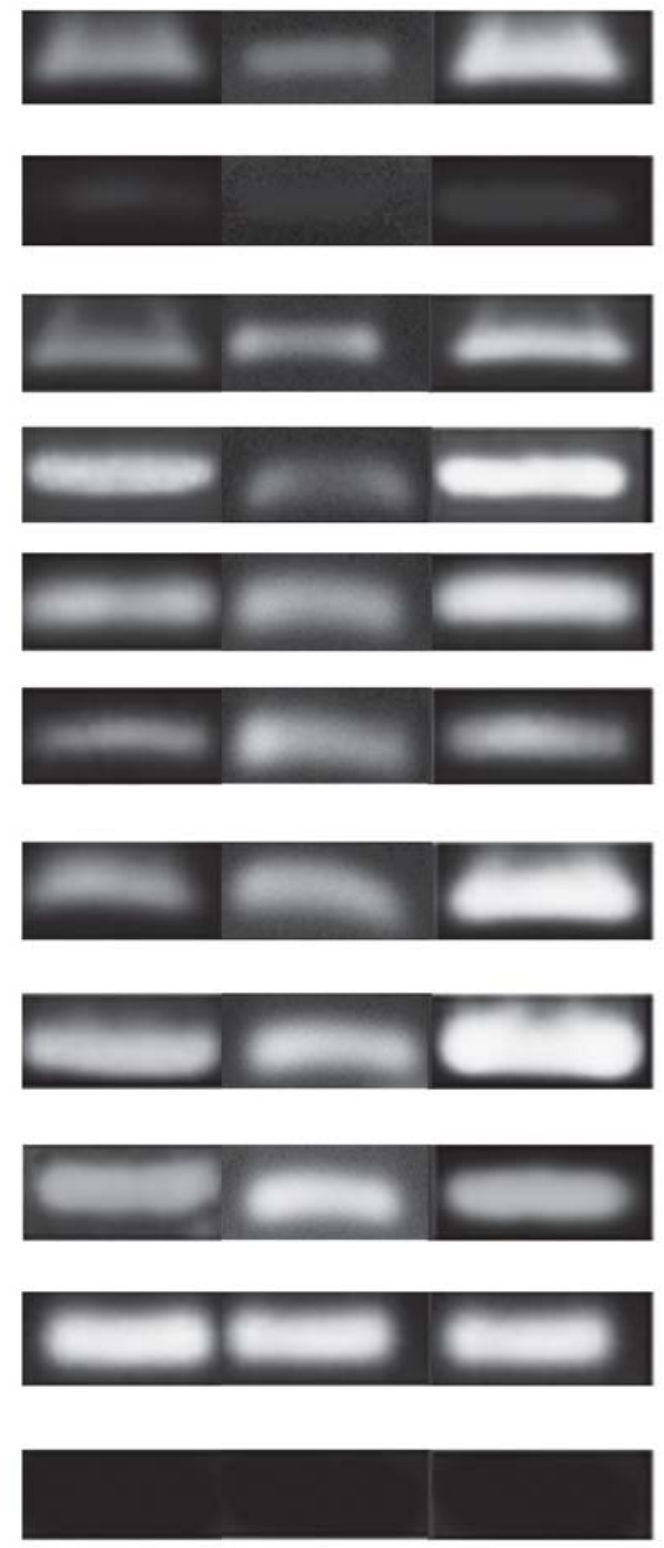

Fig. 7. Assay for gene transcription of silica, $58 \mathrm{~S}$ and bioglass disks containing zinc oxide $0.4 \%$. The indicated RTPCR products were subjected to electrophoresis on $2 \%$ agarose gel and visualized by UV exposure. The level of specific bands was normalized for GAPDH cDNA. Similar results were obtained by normalization with respect to $\beta$-actin cDNA content (data not shown).

58S-Zn0.4 surface some cell aggregates were observed. At higher magnification, some differences were observed: on the silica and 58S disks (Fig. 4, panel B and D), cells were flat and compact, whereas on the 58S-Zn0.4 disk, cells were no longer individually discernable and some, above this cell monolayer, exhibited a round shape (Fig. 4, panel F).

In order to evaluate the cell viability from all samples during the culture period, an MTT test was performed. On days $1,8,16$ and at the end of the culture period, the average cell viability of all samples was in the $86 \%-94 \%$ range without statistically significant differences $(p>0.05)$ (Data not shown).

\section{BMP 2}

\section{Bone sialoprotein}

\section{Decorin}

\section{Fibronectin}

\author{
Osteocalcin
}

\author{
Osteopontin
}

\section{TGF- $\beta$ \\ Type-I collagen}

\section{Type-III collagen}

\section{GAPDH}

\section{$-\mathrm{RT}$}

\section{Characterization of the calcified extracellular matrix} deposition

The measurement of DNA content at 24 days cell culture showed some interesting differences: the cell number from pure silica disks rose to $9.1 \times 10^{5} \pm 12.2 \times 10^{3}$, on the $58 \mathrm{~S}$ sample it reached $1.02 \times 10^{6} \pm 7.3 \times 10^{4}$ whereas on the $58 \mathrm{~S}-\mathrm{Zn} 0.4$ disks it resulted $2.04 \times 10^{6} \pm 10.4 \times 10^{4}$ $(p<0.05)$. With respect to pure silica and $58 \mathrm{~S}$ A samples, a 2 -fold increase was observed on $58 \mathrm{~S}-\mathrm{Zn} 0.4$ disks confirming the SEM observation. We did take into consideration that an underestimation of the culture cellularity is possible due to the trapping of DNA within the formed extracellular matrix. 

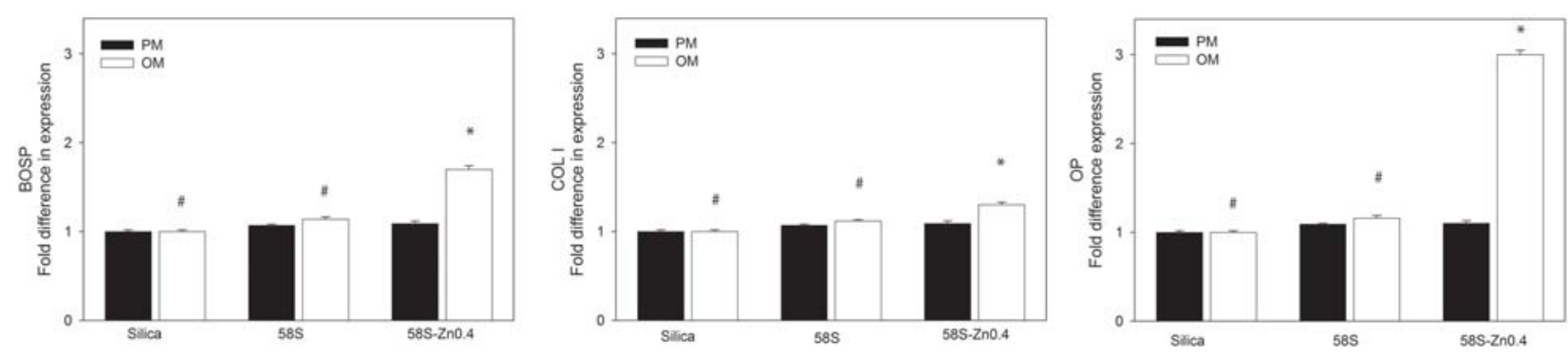

Fig. 8. Gene expression of the indicated bone-specific markers as determined by qRT-PCR. SAOS-2 cells were seeded onto silica, 58S and 58S-Zn0.4 disks and cultured in proliferative medium (PM) or in osteogenic medium $(\mathrm{OM})$. The graph shows the fold induction of gene expression expressed in arbitrary units, setting the expression of the indicated genes in cells grown on silica disks at 1 . A $p<0.001$ was considered statistically significant. Data are representative of one of the three experiments performed.

The total protein concentration was $160.5 \pm 5,1 \mu \mathrm{g} /$ $\mathrm{mL}$ on the silica, $163.7 \pm 3,8 \mu \mathrm{g} / \mathrm{mL}$ on the $58 \mathrm{~S}$, and 195.0 $\pm 6,3 \mu \mathrm{g} / \mathrm{mL}$ on the $58 \mathrm{~S}-\mathrm{Zn} 0.4$ bioglass disks.

In order to evaluate the amount of the extracellular matrix constituents produced throughout all sample types, an ELISA assay of the extracted extracellular matrix was performed. At the end of the culture period, in comparison with the silica and $58 \mathrm{~S}$ disks, the deposition of bone proteins throughout the $58 \mathrm{~S}-\mathrm{Zn} 0.4$ samples was considerably enhanced $(p<0.05)$ (Table 4$)$. The enhancement of protein deposition was evident for alkaline phosphatase (ALP), type I collagen (COLI) and osteopontin (OP): for ALP it was about 2/1.9-fold, for COLI and OP around 2/1.8 and 1.9/1.7 fold-greater when compared to pure silica and $58 \mathrm{~S}$ disks, respectively (Table 4). Protein deposition on pure silica and 58S disks was not statistically different (Table 4).

Fig. 5 shows ALP activity determined on the three types of scaffold at the end of the culture period. The level of ALP activity was consistently higher on the 58S-Zn0.4 disks than on the pure silica and 58S disks $(p<0.001)$. ALP activity was not statistically different between pure silica and 58 S disks $(p>0.05)$.

The relative amount of calcium matrix calcification on the three types of scaffold was evaluated by the calciumcresolphthalein complexone method (Fig. 6). Figure 6 shows that the mineralization of the extracellular matrix produced by SAOS-2 cells was considerably greater (almost 2-fold greater) on 58S-Zn0.4 than on silica and $58 \mathrm{~S}$ disks $(p<0.05)$. Calcium matrix deposition was not statistically different between pure silica and $58 \mathrm{~S}$ disks $(p>0.05)$.

In order to evaluate the impact of sample surfaces on ectopic extracellular matrix deposition and mineralization, the previously indicated analyses were performed with the culture medium without osteogenic factors. Unexpectedly, we did not observe significant differences in ECM deposition and mineralization on any type of disk in the absence of osteogenic factors. On the contrary, using the $58 \mathrm{~S}$ sample as an internal control, the difference in ALP activity (Fig. 5) and calcium deposition was significant only on the $58 \mathrm{~S}-\mathrm{Zn} 0.4$ disk (Fig. 6).

\section{Characterization of bone gene expression}

In order to characterize bone specific gene expression, an RT-PCR analysis was performed at 24 days culture with/ without osteogenic factors. The qualitative RT-PCR, performed on cells grown on $58 \mathrm{~S}-\mathrm{Zn} 0.4$ disks with osteogenic factors, revealed a more intense band on agarose gel for all the investigated genes and particularly for the transcripts specific for type-I collagen, bone sialoprotein and osteopontin (Fig. 7). No marked differences were observed in the absence of osteogenic factors (data not shown).

To further expand these data, an qRT-PCR for the gene expression profile of bone-specific proteins was performed at 24 days using the $\Delta \Delta \mathrm{Ct}$ method. The results showed a significant enhanced fold difference for osteopontin, collagen and bone sialoprotein $(p<0.001)$ (Fig. 8). No evident differences were detected for the other proteins $(p>0.05)$ (data not shown). Furthermore, we did not observe significant differences in bone gene expression on the sample disks cultivated in the absence of osteogenic factors (Fig. 8).

\section{Discussion}

It has been reported in the literature that the addition of zinc to silica-based bioglass leads to an increase in bioactivity (HCA formation) but, at the same time, may determine an increase in cytotoxicity (Aina et al., 2007; Balamurugan et al., 2007). In a previous study we reported preliminary evidence that a good balance between activity and toxicity, at least in vitro, can be obtained by means of carefully controlling the zinc content (Bini et al., 2009). In detail, the presence of zinc clearly increased the HCA formation rate upon immersion in SBF; this increase was proportional to the zinc content (see Fig. 1, redrawn from Bini et al. (2009). As expected, silica did not show any bioactivity.

Concerning toxicity characterization, the SAOS- 2 cell line was selected because it exhibits several fundamental osteoblast characteristics (Anderson et al., 1998) and represents a widely used and well-accepted model for in 
vitro osteoblast study. These osteoblasts can virtually grow indefinitely and uniquely exhibit osteoinductive activity, whereas other human osteosarcoma cells, such as U-2OS, do not replicate this bone-inducing ability (Anderson et al., 2002; Anderson et al., 1992; Anderson et al., 1995). The SAOS-2 cell line is useful to screen materials, but primary cells (osteoblasts, MSCs) are more relevant and should be used to assess in vitro the ability of a material surface to increase/improve biological mineralization. In the experimental conditions used for the cytotoxicity tests, we incubated human SAOS-2 osteoblasts with 58S, silica and three 58S-based bioglasses differing in their zinc content $(0.4,2$ and $5 \% \mathrm{wt})$. We observed that the presence of this metal increases, in a dose-dependent manner, the release of LDH in the extracellular medium (an index of cytotoxicity). These results are in agreement with the findings of Aina et al. (2007). The best results in terms of the LDH test were obtained with the $58 \mathrm{~S}-\mathrm{Zn} 0.4$ bioglass, which yielded results very similar to those of pure silica (positive control, see Fig. 2).

Accordingly, we focused our in vitro study on 58SZn0.4 bioglass, by performing a careful comparison with pure silica and 58S. SEM examination of silica, $58 \mathrm{~S}$ and $58 \mathrm{~S}-\mathrm{Zn} 0.4$ samples, incubated with SAOS-2 cells, showed a layer of cells and matrix on each disk. However, the appearance of the cell layer differed between each type of sample: the $58 \mathrm{~S}-\mathrm{Zn} 0.4$ disks showed a more uniform distribution and much higher number of cells and matrix on the surface analyzed. Confirming the SEM observation, cell proliferation on the 58S-Zn0.4 disks was 2-fold greater in comparison with the pure silica and $58 \mathrm{~S}$ disks. This data indirectly points to the importance of the presence of zinc in DNA replication (Chesters and Petrie, 1999; Tang et al., 2001; Li and Maret, 2009). Zinc is known to be an integral component of numerous metalloenzymes, structural proteins, and transcription factors and contributes to physiological processes including neurotransmission, hormone secretion, and DNA synthesis and gene expression. On the other hand, we cannot rule out the importance of surface roughness on cell proliferation, differentiation, protein synthesis and local factor production (Grant et al., 2008): in fact, the 58S-Zn0.4 samples showed the uppermost value of surface roughness when compared with pure silica and 58S disks. Most likely the enhancement in cell proliferation and differentiation may be due to both of these factors: the presence of zinc oxide and the roughness parameters.

A temporal and functional pattern of gene expression characterizes the osteoblast maturation process, which can be divided into proliferation, differentiation, and mineralization stages (Owen et al., 1990). It has been reported that an increase in bone formation depends on an increase in extracellular matrix synthesis (Manolagas, 2000). The deposition of type-I collagen was quite similar on pure silica and 58S disks whereas an approximate 2.0 (pure silica)- and 1.8 (58S)-fold increase was observed on $58 \mathrm{~S}-\mathrm{Zn} 0.4$ disks. Bone type-I collagen synthesis is known to be up-regulated at the proliferation stage when the osteoblasts are not confluent, and down-regulated at subsequent stages (Owen et al., 1990; Quarles et al., 1992).
A slight increment in both type-III collagen and decorin was also shown when compared with silica and $58 \mathrm{~S}$ samples: both of these proteins are known to be associated with type-I collagen (Azari et al., 2008). Other fundamental bone matrix constituents such as osteopontin, osteocalcin, osteonectin and fibronectin were also investigated. Silica and $58 \mathrm{~S}$ samples showed similar results, while the deposition of osteopontin was approximately 1.9 (pure silica)- and 1.7 (58S)-fold greater on the 58S-Zn0.4 disks. Appreciable differences for osteonectin and osteocalcin were not observed. All of these extracellular matrix proteins are organic components of bone, and are implicated in bone formation and remodelling. Osteopontin is known to play an important role in cell attachment (Van Dijk et al., 1993) and calcification of mineralized tissue (Denhardt and Guo, 1993), whereas osteocalcin (Aubin and Liu, 1996) is the latest secreted extracellular matrix protein identified. Osteonectin is a calcium and collagen binding ECM glycoprotein and also acts as a modulator of cell-matrix interactions (Bornstein and Sage, 2002). The value of fibronectin, which is reported to promote both cell adhesion and proliferation in many cell types (Grzesik and Robey, 1994; Long and Rack, 1998; Krämer et al., 1999; Wilson et al., 2003), was not significantly increased. In view of this information, the macroscopic increases in in vitro protein levels of ALP (makes the phosphate available for calcification), osteopontin (anchors the bone cells via their $\alpha V \beta 3$ integrin to the mineralized bone surface), and typeI collagen (the major organic component of bone matrix produced by osteoblasts) are quite important (Table 4). All together these results suggest that the main effect of $58 \mathrm{~S}-\mathrm{Zn} 0.4$ disks is to keep the osteoblasts in the active phase of proliferation, promoting bone ECM deposition. Furthermore, one may argue that the observed cell proliferation on $58 \mathrm{~S}-\mathrm{Zn} 0.4$ disks is simply due to differences in initial cell attachment levels vs. any real effect of the substrates: on day 1, comparable values of cell attachment on all sample types were observed (data not shown), suggesting that subsequent variation in cell proliferation may be due to the composition of the sample and not to differences in cell attachment.

Interestingly, the qRT-PCR analysis showed an increase in type-I collagen, bone sialoprotein, and osteopontin gene expression levels from the 58S-Zn0.4 samples. As type-I collagen and osteopontin are critical in mediating the signal cascade for the full expression of the mature osteoblast phenotype and the mineralization of the extracellular matrix (Lynch et al., 1995; Kobayashi et al., 1998; Kojima et al., 2004), the higher COL I and OP gene expression in SAOS-2 cells could be related to the cell's ability to better differentiate toward mature osteoblasts and to deposit mineralized bone matrix onto $58 \mathrm{~S}-\mathrm{Zn} 0.4$ bioglass. This concept is also true for BSP, which is a significant component of the bone extracellular matrix and has been suggested to constitute approximately $8 \%$ of all noncollagenous proteins found in bone and cementum (Fisher, 1990). In summary, the increased transcription of these genes could indicate the early phase of cell differentiation. The increase in the transcript levels of COLI, OP and BSP genes was supported by the mineralization data. 
Quantitative analysis of the calcium mineral content showed that SAOS-2 cells were able to deposit a significantly higher amount of newly mineralized matrix onto 58S-Zn0.4 disks than onto pure silica and 58S disks: approximately a 2-fold difference in matrix calcification was detected. In addition the $58 \mathrm{~S}-\mathrm{Zn} 0.4$ disks showed a faster and higher HCA formation than $58 \mathrm{~S}$ samples indicating that at an earlier stage $\mathrm{Ca}$ deposition is due to physical-chemical characteristics of zinc-containing disks as indicated by the bioactivity test (Fig. 1). Then, Ca deposition becomes a biologically mediated mineralization process. Unfortunately, due to the intrinsic fluorescence of both silica and bioglass disks, it was not possible to perform confocal microscopic analysis to localize the calcification and bone matrix proteins in the cell-rich areas.

In this study, the increase in calcium deposition was consistent with the rise in alkaline phosphatase expression. The protein content was almost 2/1.9-fold greater for the $58 \mathrm{~S}-\mathrm{Zn} 0.4$ than for silica and 58S samples. An increase of almost 2-fold in ALP activity was also shown on the 58SZn0.4 disks with respect to both pure silica and 58S. ALP is known as an important component in hard tissue formation, highly expressed in mineralized tissue cells. Osteoblast cells grown with ascorbic acid sequentially express osteoblastic marker proteins such as alkaline phosphatase and then form a mineralized extracellular matrix (ECM) as a consequence of osteoblastic differentiation. The importance of ALP in the mineralization of ECM has been previously reported (Torii et al., 1996). Its mechanism of action is not completely known but it appears both to promote the local concentration of inorganic phosphate, a mineralization promoter, and to decrease the concentration of extracellular pyrophosphate, an inhibitor of mineral formation (Torii et al., 1996). Previous authors have reported that alkaline phosphatase is expressed in large amounts in osteoblasts in vivo (Zernick et al., 1990), but it has also been found in differentiation studies with osteoblast-like cell lines in vitro (Gerstenfeld et al., 1987). The elevated expression of ALP (which occurs at the end of the cell proliferative state) osteopontin and bone sialoprotein may suggest that the osteoblasts on the $58 \mathrm{~S}-\mathrm{Zn} 0.4$ disks are more differentiated than those on the pure silica and $58 \mathrm{~S}$ disks and have already started to promote bone ECM deposition. In summary, addition of zinc oxide is beneficial for bone matrix deposition and expression on bioactive glass disks. Furthermore, the antimicrobial activity associated with zinc oxide could be considered an added value to clinically implanted biomaterials (Aydin Sevinç and Hanley, 2010).

\section{Conclusions}

This study confirms that the presence of a high level of zinc is cytotoxic to osteoblast survival, whereas a $0.4 \% \mathrm{wt}$ zinc oxide in 58S samples improves the environment and favours osteoblast proliferation and function. Moreover, the $58 \mathrm{~S}-\mathrm{Zn} 0.4$ samples showed the highest value for surface roughness when compared with pure silica and 58S disks. Consequently, the enhanced deposition and mineralization of the extracellular matrix by osteoblasts on the 58S-Zn0.4 samples may possibly be due not merely to the presence of zinc but also to the higher surface roughness.

Prospectively, we believe that bioglasses containingzinc could be successfully employed as implants in clinical applications: the incorporation of zinc oxide into bioactive glass would also enhance antimicrobial properties of the original material.

Further in vivo studies on the potential clinical applications of $\mathrm{Zn}$-containing $58 \mathrm{~S}$ bioglass need to be performed.

\section{Acknowledgements}

This work was supported by the Fondazione Cariplo Grants (2006.0581/10.8485), by a PRIN Grant (2006) from the Italian Ministry of Education, University and Research to L. V., and by a FIRB Grant (RBIP06FH7J) from the Italian Ministry of Education, University and Research to M.G. C. De A. The support of the Regione Lombardia (Project REGLOM16) is also recognized.

The authors would like to acknowledge financial support by "Project SAL-45" financed by Regione Lombardia and by project titled "Nanomedicine in ageingassociated prototypic diseases: activation of a scientific and technological platform challenging seminal aspects of pathogenesis, diagnosis and therapy" financed by FONDAZIONE ALMA MATER TICINENSIS (2010).

We are grateful to D. Picenoni for technical assistance in the scanning electron microscopic studies and M. Ronchi for profilometry analysis.

Special thanks to G. Magenes and F. Benazzo for reviewing the manuscript and Laurene Kelly for correcting the English.

\section{References}

Aina V, Perardi A, Bergandi L, Malavasi G, Menabue L, Morterra C, Ghigo D (2007) Cytotoxicity of zinccontaining bioactive glasses in contact with human osteoblasts. Chem-Biol Interact 167: 207-218.

Anderson HC, Sugamoto K, Morris DC, Hsu HH, Hunt $\mathrm{T}$ (1992) Bone-inducing agent(BIA) from cultured human Saos-2 osteosarcoma cells. Bone Miner 16: 49-62.

Anderson HC, Hsu HH, Raval P, Hunt TR, Schwappach JR, Morris DC, Schneider DJ (1995) The mechanism of bone induction and bone healing by human osteosarcoma cell extracts. Clin Orthop Relat Res 313: 129-134.

Anderson HC, Hsu HHT, Raval P, Reynold PR, Gurley DJ, Aguilera MX, Davis LS, Moylan PE (1998) Boneinducing agent in Saos-2 cell extracts and secretions. Cells Mater 8: 89-98.

Anderson HC, Reynolds PR, Hsu HH, Missana L, Masuhara K, Moylan PE, Roach HI (2002) Selective synthesis of bone morphogenetic proteins- $1,-3,-4$ and bone sialoprotein may be important for osteoinduction by Saos-2 cells. J Bone Miner Metab 20: 73-82. 
Aubin JE, Liu F (1996) The osteoblast lineage. In: Principles of Bone Biology (Bilezkian JP, Raisz LG, Rodan GA, eds). Academic Press, San Diego, CA, USA, pp 5167.

Aydin Sevinç B, Hanley L (2010) Antibacterial activity of dental composites containing zinc oxide nanoparticles. J Biomed Mater Res B Appl Biomater 94: 22-31.

Azari F, Valli H, Guerquin-Kern J, Wu TD, Croysi A, Tabrizian M, McKee MD (2008) Intracellular precipitation of hydroxyaptite mineral and implications for pathological calcification. J Struct Biol 162: 468-479.

Balamurugan A, Balossier G, Kannan S, Michel J, Rebelo AHS, Ferreira MF (2007) Development and in vitro characterization of sol-gel derived CaO-P2O5-SiO2-ZnO bioglass. Acta Biomaterialia 3: 255-262.

Bini M, Grandi S, Capsoni D, Mustarelli P, Saino E, Visai $\mathrm{L}$ (2009) $\mathrm{SiO}_{2}-\mathrm{P}_{2} \mathrm{O}_{5}-\mathrm{CaO}$ glasses and glass-ceramics with and without $\mathrm{ZnO}$ : relationships among composition, microstructure and bioactivity. J Phys Chem C 113: 88218828.

Bornstein P, Sage EH (2002) Matricellular proteins: extracellular modulators of cell function. Curr Opin Cell Biol 14: 608-616.

Brinker CJ, Scherer GW (1990) Sol-Gel Science: The Physics and Chemistry of Sol-Gel Processing. Academic Press, New York.

Bruker AXS (2005) TOPAS V3.0: General profile and structural analysis software for powder diffraction data. User Manual., Bruker AXS, Karlsruhe, Germany.

Chesters JK, Petrie L. (1999) A possible role for cyclins in the zinc requirements during G1 and G2 phases of the cell cycle. J Nutr Biochem 10: 279-290.

Cohen SA, Sideman L (1979) Modification of the ocresolphthalein complexone method for determining calcium. Clin Chem 25: 1519-1520.

Courtheoux L, Lao J, Nedelec J-M, Jallot E (2008) Controlled Bioactivity in Zinc-Doped Sol-Gel-Derived Binary Bioactive Glasses. J Phys Chem C 112: 13663 13667.

Denhardt DT, Guo X (1993) Osteopontin: a protein with diverse functions. FASEB J 7: 1475-1482.

Fisher LW, McBride OW, Termine JD, Young MF (1990) Human bone sialoprotein. Deduced protein sequence and chromosomal localization. J Biol Chem 265: 2347-2351.

Gartland A, Buckley KA, Dillon JP, Curran JM, Hunt JA, Gallagher JA (2005) Isolation and culture of human osteoblasts. Methods Mol Med 107: 29-54.

Gerstenfeld LC, Chipman SD, Glowacki J, Lian JB (1987) Expression of differentiated function by mineralizing cultures of chicken osteoblasts. Dev Biol 122: 49-60.

Grant DM, Lo WJ, Scotchford CA (2008) The effect of different surface morphology and roughness on osteoblast-like cells. Biomed Mater Res A 86: 637-647.

Grzesik WJ, Robey PG (1994) Bone matrix RGD glycoproteins: immunolocalization and interaction with human primary osteoblastic bone cells in vitro. J Bone Miner Res 9: 487-496.

Hench LL (1998) Bioceramics. J Am Ceram Soc 81: 1705-1728.
Hench LL, Paschall HA (1973) Direct chemical bond of bioactive glass-ceramic materials to bone and muscle. J Biomed Mater Res 7: 25-42.

Hench LL, Splinter RJ, Allen WC, Greenlee Jr TK (1971) Bonding mechanism at the interface of ceramic prosthetic materials. J Biomed Mater Res 5: 117-141.

Holtorf HL, Datta N, Jansen JA, Mikos AG (2005) Scaffold mesh size affects the osteoblastic differentiation of seeded marrow stromal cells cultured in a flow perfusion bioreactor. J Biomed Mater Res A 74: 171-180.

Ito A, Kawamura H, Otsuka M, Ikeuchi M, Ohgushi H, Ishikawa K, Onuma K, Kanzaki N, Sogo Y, Ichinose N (2002) Zinc-releasing calcium phosphate for stimulating bone formation. Mater Sci Eng C 22: 21-25.

Izquierdo-Barba I, Arcos D, Sakamoto Y, Terasaki O, Lopez-Noriega A, Vallet-Regi M (2008) High-performance mesoporous bioceramics mimicking bone mineralization. Chem Mater 20: 3191-3198.

Kobayashi E, Wang TJ, Doi H, Yoneyama T, Hamanaka H (1998) Mechanical properties and corrosion resistance of Ti-6Al-7Nb alloy dental castings. J Mater Sci Mater Med 9: 567-574.

Kojima H, Uede T, Uemura T (2004) In vitro and in vivo effects of the overexpression of osteopontin on osteoblast differentiation using a recombinant adenoviral vector. J Biochem 136: 377-386.

Kokubo T, Kushitani H, Sakka S, Kitsugi T, Yamamuro $\mathrm{T}$ (1990) Solutions able to reproduce in vivo surfacestructure changes in bioactive glassceramic. J Biomed Mater Res 24: 721-734.

Krämer A, Horner S, Willer A, Fruehauf S, Hochhaus A, Hallek M, Hehlmann R (1999) Adhesion to fibronectin stimulates proliferation of wild-type and bcr/abltransfected murine hematopoietic cells. Proc Natl Acad Sci USA 96: 2087-2092.

Li R, Clark AE, Hench LL (1991) An investigation of bioactive glass powders by sol-gel processing. J Appl Biomater 2: 231-239.

Li Y, Maret W (2009) Transient fluctuations of intracellular zinc ions in cell proliferation. Exp Cell Res 315: 2463-24670.

Linati L, Lusvardi G, Malavasi G, Menabue L, Menziani MC, Mustarelli P, Segre U (2005) Qualitative and quantitative structure"property relation. J Phys Chem B 109: 4989-4998.

Long M, Rack HJ (1998) Titanium alloys in total joint replacement - a materials science perspective. Biomaterials 19: 1621-1639.

Lusvardi G, Malavasi G, Menabue L, Menziani MC (2002) Synthesis, Characterization, and Molecular Dynamics Simulation Of Na2O-CaO-SiO2-ZnO Glasses. J Phys Chem B 106: 9753-9760.

Lynch MP, Stein JL, Stein GS, Lian JB (1995) The influence of type I collagen on the development and maintenance of the osteoblast phenotype in primary and passaged rat calvarial osteoblasts: modification of expression of genes supporting cell growth, adhesion, and extracellular matrix mineralization. Exp Cell Res 216: 35 45.

Manolagas SC (2000) Birth and death of bone cells: basic regulatory mechanisms and implications for the 
pathogenesis and treatment of osteoporosis. Endocr Rev

21: 115-137.

Ohtsuki C, Kokubo T, Yamamuro T (1992) Mechanism of apatite formation on $\mathrm{CaO}-\mathrm{SiO}_{2}-\mathrm{P}_{2} \mathrm{O}_{5}$ glasses in a simulated body fluid. J Non-Cryst Solids 143: 84-92.

Oki A, Parveen B, Hossain S, Adeniji S, Donahue H (2004) Preparation and in vitro bioactivity of zinc containing sol-gel-derived bioglass materials. J Biomed Mater Res A 69: 216-221.

Oliva A, Salerno A, Locardi B, Riccio V, Della Ragione F, Iardino P, Zappia V (1998) Behaviour of human osteoblasts cultured on bioactive glass coatings. Biomaterials 19: 1019-1025.

Owen TA, Aronow M, Shalhoub V, Barone LM, Wilming L, Tassinari MS, Kennedy MB, Pockwinse S, Lian JB, Stein GS (1990) Progressive development of the rat osteoblast phenotype in vitro: reciprocal relationships in expression of genes associated with osteoblast proliferation and differentiation during formation of the bone extracellular matrix. J Cell Physiol 143: 420-430.

Quarles LD, Yohay DA, Lever LW, Caton R, Wenstrup RJ (1992) Distinct proliferative and differentiated stages of murine MC3T3-E1 cells in culture: an in vitro model of osteoblast development. J Bone Miner Res 7: 683-692.

Rao LG, Liu LJ, Murray TM, McDermott E, Zhang X. (2003) Estrogen added intermittently, but not continuously, stimulates differentiation and bone formation in SaOS-2 cells. Biol Pharm Bull 26: 936-945.

Rossi A, Zuccarello LV, Zanaboni G, Monzani E, Dyne KM, Cetta G, Tenni R (1996) Type I collagen CNBr peptides: species and behaviour in solution. Biochemistry 35: 6048-6057.

Saino E, Maliardi V, Quartarone E, Fassina L, Benedetti L, De Angelis MG, Mustarelli P, Facchini A, Visai L. (2010) In vitro enhancement of SAOS-2 cell calcified matrix deposition onto radio frequency magnetron sputtered bioglass-coated titanium scaffolds. Tissue Eng Part A 16: 995-1008.

Tang ZL, Wasserloos K, St. Croix CM, Pitt BR (2001) Role of zinc in pulmonary endothelial cell response to oxidative stress. Am J Physiol Lung 281: 243-249.

Torii Y, Hitomifl K, Yamagishi Y, Tsukagoshi N (1996) Demonstration of alkaline phosphatase participation in the mineralization of osteoblasts by antisense RNA approach. Cell Biol Int 20: 459-464.

Vallet-Regi M (2006) Revisiting ceramics for medical application. Dalton Trans 44: 5211-5220.

Vallet-Regí M, Ragel CV, Salinas AJ (2003) Glasses with medical applications. Eur J Inorg Chem 2003: 10291042 .
Van Dijk S, D’ Errico JA, Somemen MJ, Farach-Carson MC, Butler WT (1993) Evidence that a non-RGD domain in rat osteopontin is involved in cell attachment. J Bone Miner Res 8: 1499-1506.

Vogel KG, Evanko SP (1987) Proteoglycans of fetal bovine tendon. J Biol Chem 262: 13607-13613.

Vuento M, Vaheri A (1979) Purification of fibronectin from human plasma by affinity chromatography under nondenaturing conditions. Biochem J 183: 331-337.

WHO expert committee on trace elements in human nutrition (1973) WHO Tech Rep Ser 532: 9-15.

Wilson SH, Ljubimov AV, Morla AO, Caballero S, Shaw LC, Spoerri PE, Tarnuzzer RW, Grant MB (2003) Fibronectin fragments promote human retinal endothelial cell adhesion and proliferation and ERK activation through alpha5beta1 integrin and PI 3-kinase. Invest Ophthalmol Vis Sci 44: 1704-1715.

Yamaguchi M, Inamoto K, Suketa Y (1986) Effect of essential trace metals on bone metabolism in weanling rates: comparison with zinc and other metals action. Res Exp Med 186: 337-342.

Yamaguchi M, Inamoto K, Suketa Y (1987) Stimulatory effects of zinc on bone formation in tissue culture. Biochem Pharmacol 36: 4007-4012.

Yamaguchi M, Igarashi A, Ychiyama S (2004) Bioavailability of zinc yeast in rats: stimulatory effect on bone calcification in vivo. J Health Sci 50: 75-81.

Zernick J, Twarog K, Upholt WB (1990) Regulation of alkaline phosphatase and alfa 2(1) procollagen synthesis during early intramembranous bone formation in the rat mandible. Differentiation 44: 207-215.

\section{Discussion with Reviewer}

Reviewer II: Did the authors perform any control experiments to clarify if the changes in topography altered the expression of GAPDH? Obviously, the stability/ constant expression of the housekeeping gene is of utmost importance for the results to be valid. Given that GAPDH is involved in cell metabolism, and this pathway can be affected by changes in topography, it is important that this be investigated.

Authors: We performed control experiments to clarify whether the changes in topography altered the expression of GAPDH. We did not observe any significant changes in the expression of GAPDH. 